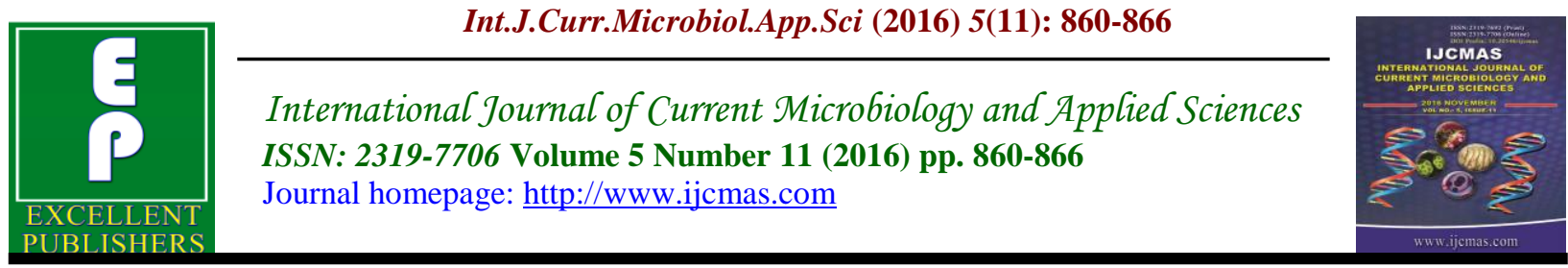

Original Research Article

http://dx.doi.org/10.20546/ijcmas.2016.511.098

\title{
Antibacterial and Antifungal Activities of Gossypitrin from Talipariti elatum Sw. (Fryxell)
}

\section{José González ${ }^{1}$, Armando Cuéllar ${ }^{1}$, Loïk Sylvius ${ }^{2}$, Frédéric Verdeau ${ }^{2}$, Juliette Smith-Ravin' and Odile Marcelin ${ }^{2}$}

${ }^{1}$ Department of Pharmacy, Faculty of Pharmacy and Foods, Havana University

${ }^{2}$ Université des Antilles, EA929 AIHP-GEODE Groupe BIOSPHERES, Campus Universitaire de Schoelcher, BP 7209, 97275, Schoelcher Cedex, Martinique

*Corresponding author

Keywords

Talipariti elatum, gossypitrin, antimicrobial, antibacterial, antifungal.

\begin{tabular}{l}
\hline Article Info \\
\hline Accepted: \\
20 October 2016 \\
Available Online: \\
10 November 2016
\end{tabular}

\section{A B S T R A C T}

The present study investigated the antibacterial and antifungal activities in vitro of gossypitrin, a flavonoid glucoside isolated and characterized from the ethanolic extracts of Talipariti elatum Sw. (Fryxell). The inhibition activity against bacteria was $53.85 \%$, while inhibition activity against fungal was $15.38 \%$. The antibacterial activity of gossypitrin against Staphylococcus epidermidis, Proteus vulgaris and Klebsiella pneumoniae, showed varying degrees of inhibition on the tested organisms. Only two of 13 fungal strains were inhibited, Candida albicans and Candida subtilis.

\section{Introduction}

Flavonoids are known to be synthesized by plants in response to microbial infection; thus it should not be surprising that they have been found in vitro to be effective antimicrobial substances against a wide array of microorganisms. Flavonoid rich plant extracts from different species have been reported to possess antibacterial activity (Mishra et al., 2013; Mishra et al., 2013, 2011; Pandey et al., 2010). Several flavonoids including apigenin, galangin, flavone and flavonol glycosides, isoflavones, flavanones, and chalcones have been shown to possess potent antibacterial activity (Cushnie et al., 2005). Antibacterial flavonoids might be having multiple cellular targets, rather than one specific site of action. One of their molecular actions is to form complex with proteins through nonspecific forces such as hydrogen bonding and hydrophobic effects, as well as by covalent bond formation. Thus, their mode of antimicrobial action may be related to their ability to inactivate microbial adhesins, enzymes, cell envelope transport proteins, and so forth. Lipophilic flavonoids may also disrupt microbial membranes (Cowan, 1999; Mishra et al., 2009). 
Catechins, the most reduced form of the $\mathrm{C} 3$ unit in flavonoid compounds, have been extensively researched due to their antimicrobial activity. These compounds are reported for their in vitro antibacterial activity against Vibrio cholerae, Streptococcus mutans, Shigella, and other bacteria (Borris, 1996). The catechins have been shown to inactivate cholera toxin in Vibrio cholera and inhibit isolated bacterial glucosyl transferases in S. mutans, probably due to complexing activities (Borris, 1996). Robinetin, myricetin, and (-)epigallocatechin are known to inhibit DNA synthesis in Proteus vulgaris. Mori et al. (1987) suggested that the B ring of the flavonoids may intercalate or form hydrogen bond with the stacking of nucleic acid bases and further lead to inhibition of DNA and RNA synthesis in bacteria. Another study demonstrated inhibitory activity of quercetin, apigenin, and 3, 6, 7, 3', 4'pentahydroxyflavone against Escherichia coli DNA gyrase (Ohemeng et al., 1993).

Naringenin and sophoraflavanone $G$ have intensive antibacterial activity against methicilline resistant Staphylococcus aureus (MRSA) and streptococci. An alteration of membrane fluidity in hydrophilic and hydrophobic regions may be attributed to this effect which suggests that these flavonoids might reduce the fluidity of outer and inner layers of membranes. The correlation between antibacterial activity and membrane interference supports the theory that flavonoids may demonstrate antibacterial activity by reducing membrane fluidity of bacterial cells.

Talipariti elatum is native to the islands of Cuba, Jamaica, US Virgin Islands, Puerto Rico and Martinica. In wetter areas it will grow in a wide range of elevations, up to 1200 meters $(3900$ Ft.) and is often used in reforestation. It is the national tree of
Jamaica. Talipariti elatum tree is quite attractive with its straight trunk, broad green leaves and hibiscus-like flowers. The attractive flower changes color as it matures, going from bright yellow to orange red and finally to crimson (Figure 1). It grows quite rapidly, often attaining 20 meters (66 Ft.) or more in height. The name mahoe is derived from a Caribe word. The "blue" refers to blue-green streaks in the polished wood, giving it a distinctive appearance.

Whereas the pattern of flavonoids and polyphenol derivatives in T. elatum has been studied in detail and showed qualitative conformity among these species (Cuéllar et al., 2001), only very few data on flavonoids in T. elatum are available. Until now, only gossypitrin (gossypetin-7-O- $\beta$-Dglucoside) has been reported in Cuba (Cuéllar et al., 2010). In Blue Mahoe trees that are harvested in Martinica, Martinican researchers revealed the presence for the first time of gossypetin-3'- $O$-glucoside, an isomeric molecule of gossypitrin.

The aim of this study was to evaluate the antimicrobial activity in vitro of gossypitrin against bacterial and fungal strains.

\section{Materials and Methods}

\section{Plant Material}

Flowers were collected in January 2015 in the gardens of the Faculty of Pharmacy and Foods at Havana University, and identified at the herbarium of National Botany Garden of Havana, where the voucher specimen no. HAJB 82587 has been deposited.

\section{Extract and Samples Preparation}

Dark red flowering types were collected daily. The isolated petals used were dried in an oven with controlled temperature, at 
$40^{\circ} \mathrm{C}$, during 5 days. The extracts were prepared with the ground material $(60 \mathrm{~g})$ without screen extracted in a Soxhlet apparatus with $675 \mathrm{~mL}$ of ethanol at $95 \%$ during 20 hours. The ethanolic extracts were concentrated and evaporated under vacuum to $200 \mathrm{~mL}$ at $120 \mathrm{rpm}$, a temperature of $70^{\circ} \mathrm{C}$ and 500 mbar. For to the purification, $1 \mathrm{~g}$ of solid was dissolved in $25 \mathrm{~mL}$ of diethyl ether and the volume was completed to $100 \mathrm{~mL}$ with ethanol. The sample was refrigerated until an abundant solid appear and it was recuperated to filtration. This process was done twice, to obtain only a yellowish-green solid monitoring by TLC on silica gel with fluorescent indicator $254 \mathrm{~nm}$ on aluminum cards (layer thickness $0.2 \mathrm{~mm}$ ) $(10 \times 20 \mathrm{~cm})$ using n-butanol: acetic acid: water (4:1:5) as eluent (v/v/v) (Yaque et al., 2016).

\section{Antibacterial activity assay}

In the antimicrobial activity evaluation were used 26 strains of bacteria (Gram + and Gram -), where only one was from clinical origin, and 13 strains of fungus of Candida genus (all of them collection strains). The maximum concentration of gossypitrin employed in the research to determinate $\mathrm{MIC}$ and $\mathrm{MBC}$ was $50 \mathrm{mg} / \mathrm{mL}$ in base of the solubility of the flavonoid. The value of MBC or MFC corresponding to the minimum concentration in which gossypitrin inhibited the microorganism grows.

The antibacterial activity of the extracts was determined using the agar cup diffusion as described by Biavati et al., 2008. A $1 \mathrm{~mL}$ of an overnight culture of each bacterial isolate (equivalent to 107 to $108 \mathrm{CFU} \mathrm{mL}-1$ ) was used to seed sensitivity test agar plates maintained at $45^{\circ} \mathrm{C}$. The seeded plates were allowed to set, and a sterile cork borer of 8 $\mathrm{mm}$ diameter was used to cut equidistant wells on the surface of the agar. The wells were filled with $0.1 \mathrm{~mL}$ solution of each extract reconstituted with methanol at a concentration of $10 \mathrm{mg} \mathrm{mL}-1$. Gentamycin and Nistatin at $5 \mu \mathrm{g} \mathrm{mL}-1$ were included as positive control. The plates were incubated at $37^{\circ} \mathrm{C}$ for $24 \mathrm{~h}$ after which the diameter of zones of inhibition were measured.

\section{Statistical analysis}

All analysis were conducted in triplicate (n $=3$ ), and an ANOVA test (using SPSS statistical software) was used to compare the mean values of each treatment. Significant differences between the means of parameters were determined by using the Duncan test $(\mathrm{p}<0.05)$.

\section{Results and Discussion}

Antibacterial activity test showed that gossypitrin had growth inhibitory effect on several tested microorganism. Inhibition zone was wide against $S$. epidermidis, $P$. vulgaris, K. pneumoniae, E. coli, S. aureus, E. faecium, Sh. flexneri and $C$. freundii. The flavonoid glucoside of $T$. elatum showed equal inhibition ability against $E$. coli and $S$. aureus $(40 \mathrm{~mm})$ which was highest than $B$. subtilis $(28 \mathrm{~mm})$ and $S$. typhi $(27 \mathrm{~mm})$. The phytochemical component exhibited higher inhibition ability against $S$. epidermidis (47 $\mathrm{mm})$ than against $P$. vulgaris $(35 \mathrm{~mm})$ and K. pneumoniae $(33 \mathrm{~mm})$.

In the present study, a variety of gram positive ( $S$. aureus and $S$. epidermidis) and gram negative ( $E$. coli and $P$. vulgaris) bacteria were used in screening antimicrobial activity of gossypitrin, the main isolated and characterized flavonoid glucoside from the ethanolic extracts of Talipariti elatum $\mathrm{Sw}$ in Cuba. The results of the current study clearly indicated that this flavonol glucoside inhibit the growth of some tested microorganisms, however, the effectiveness varied against the different tested microorganisms as shown in Table 1. 
Table.1 Antibacterial evaluation of gossypitrin isolated from the petals of T. elatum $\mathrm{Sw}$.

\begin{tabular}{|c|c|c|c|c|}
\hline Strains & ATCC & Screening & $\mathrm{MIC}(\mathrm{mg} / \mathrm{mL})$ & $\mathrm{MBC}(\mathrm{mg} / \mathrm{mL})$ \\
\hline Salmonella typhi & 7251 & + & 50 & 40 \\
\hline Serratia marcescens & 14056 & - & & \\
\hline Klebsiella pneumoniae & 13883 & + & 10 & 10 \\
\hline Providencia sp. & $c-3450$ & + & 40 & 40 \\
\hline Alcalaigenes faecalis & 1460 & - & & \\
\hline Streptococcus faecalis & 29212 & - & & \\
\hline Escherichia coli & 35150 & + & 20 & 20 \\
\hline Escherichia coli & 25922 & - & & \\
\hline Staphylococcus aureus & 25923 & + & 50 & 50 \\
\hline Shigella flexneri & 12022 & + & 30 & 30 \\
\hline Citrobacter freundi & 8090 & + & 50 & 40 \\
\hline Bacillus subtilis & 6633 & + & 50 & 50 \\
\hline Proteus mirabilis & 12453 & - & & \\
\hline Streptococcus cloacae & 23353 & - & & \\
\hline Salmonella typhimunium & 14028 & - & & \\
\hline Salmonella enteriditis & 13076 & - & & \\
\hline Enterococcus aerogenes & 13048 & - & & \\
\hline Proteus mirabilis & 7202 & - & & \\
\hline Staphylococcus aureus & 6538 & - & & \\
\hline Salmonella typhi & 19430 & - & & \\
\hline Staphylococcus aureus & 33862 & + & 20 & 20 \\
\hline Proteus vulgaris & 13315 & + & 10 & 5 \\
\hline Enterococcus faecium & 6056 & + & 30 & 20 \\
\hline Citrobacter freundii & 10625 & + & 30 & 30 \\
\hline Staphylococcus aureus & clinical & + & 20 & 20 \\
\hline Staphylococcus epidermidis & 12228 & + & 5 & 5 \\
\hline
\end{tabular}


Fig.1 Flowers of Talipariti elatum Sw.

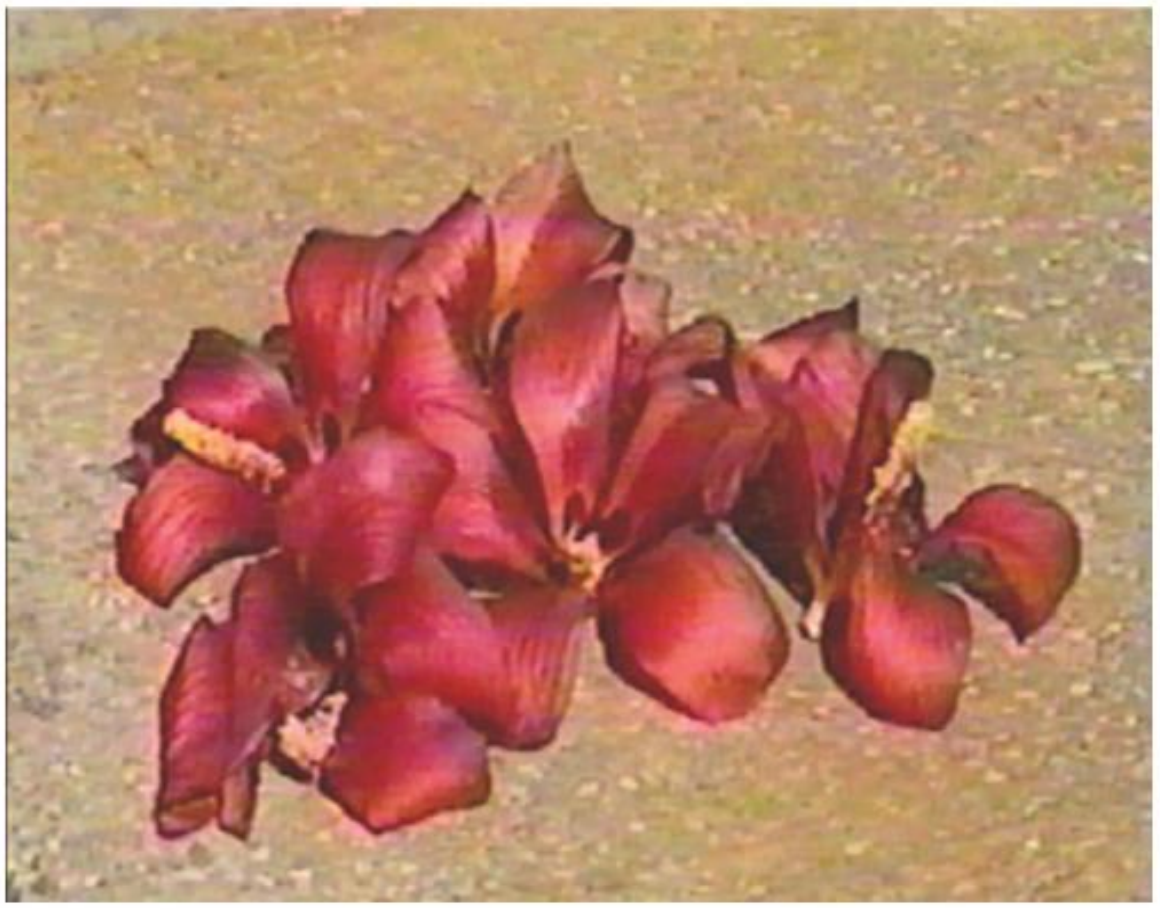

The best results found in from of the different gram positive and gram negative bacterias used in the research were against $S$. epidermidis, $P$. vulgaris and $K$. pneumoniae, where the MIC and MBC were the lowest values at $5-5 \mathrm{mg} / \mathrm{mL}, 10-5 \mathrm{mg} / \mathrm{mL}$ and $10-$ $10 \mathrm{mg} / \mathrm{mL}$, respectively. The chemical component had an antibacterial effect of 53, $85 \%$, being positive its inhibition effect in front of 14 of the 26 strains of evaluated microorganisms. Only in front of two of 13 strains of fungus had a good effect (15, $38 \%$ ). Antifungal activity of gossypitrin against Candida subtilis and Candida albicans showed values at $20 \mathrm{mg} / \mathrm{mL}$. The last one is an opportunistic fungus present in inmunodepression conditions and it which is very resistant to the treatment with conventional medication.

The antibacterial activity of the cycle extracts of $H$. sabdariffa can be attributed to the action of the phytochemical compounds it contains (Babayi et al., 2004). These bioactive compounds are known to act by different mechanism and exert antimicrobial action. Flavonoids are hydroxylated phenolic substance known to be synthesized by plants in response to microbial infection and it should not be surprising that they have been found in vitro to be effective antimicrobial substances against a wide array of microorganisms. Their activity is probably due to their ability to complex with extracellular and soluble proteins and to complex with bacterial cell walls. These results agree with Garcia- Alonso et al., (2006) who found that plant polyphenols have been demonstrated as potential antibacterial. Polyphenolic compounds and/or volatile oils are known to inhibit a wide range of organisms (Cheesbrough, 1984). Antibacterial activity of gossypetin isolated from $H$. sabdariffa was investigated and the activity may be due to Polyphenolic nature of the flavonoid gossypetin (Mounnissamy et al., 2002; Al-Hashimi, 2012).

Is important to remind that, up to now, only four flavonoid glycosides have been found in nature derivatives from gossypetin: 
Gossypetin-8-O-glucoside or gossypin ( $H$. vitifolius and $H$. sabdariffa); Gossypetin-7$O$-glucoside or gossypitrin or gossypetrin (H. sabdariffa, T. elatum and T. tiliaceum); Gossypetin-3-O-glucoside or gossytrin ( $H$. sabdariffa and T. tiliaceum) and Gossypetin3'-O-glucoside (Abelmoschus manihot and T. elatum)(18). Antibacterial effects of this plant flavonoid against Escherichia coli, S. epidermidis and $S$. aureus suggest that they may possess remarkable therapeutic action in the treatment of gastrointestinal infection and diarrhea in man and skin diseases (Rogger et al., 1990). The good result of the antibacterial evaluation against $K$. pneumoniae leads to futures opportunities in th treatment of asthma and bronchial infections, especially in tropical countries.

In conclusion, the present study indicated that gossypitrin from the petals of $T$. elatum (Sw.) Fryxell, have significant antimicrobial and antifungal activity. Gossypitrin, the isolated glucoside flavonol from alcoholic extracts of Blue Mahoe in Cuba, effectively inhibited the growth of $S$. epidermidis, P.vulgaris, $K$. pneumoniae, E. coli, $S$. aureus, C. albicans and C. subtilis. Over another 11 different strains of bacteria possess a remarkable inhibitory effect. This fact lead us to the conclusion that gossypitrin might be an alternative source of antimicrobial compounds.

\section{References}

Al-Hashimi A.G. 2012. Antioxidant and antibacterial activities of Hibiscus sabdariffa Lextracts. African J. Food Sci., Vol. 6(21) pp. 506-511, 15.

Babayi, H., Kolo, I., Okogun, I., Ijah, J. 2004. The antimicrobial activities of methanolicextracts of Eucalyptus camaldulensis and Terminalia catappa against some pathogenic microorganisms. Biokemistri, 6: 106-111.

Biavati, R., Piceaglia, B., Marotti, M. 2008.
Antimicrobial activity of plant essential oils'.Dep. of Agro environmental Science and Technology University of Bologna.http://www.ienica.net/italysemi nar/greenchem/biavatipresentation.pdf

Borris, R.P. 1996. Natural products research: perspectives from a major pharmaceuticalcompany. $J$. Ethnopharmacol., vol.51, no.1-3, pp.29-38.

Cheesbrough, M. 1984. Tropical Health Technology. Cambridge University Press, U.K. p479.

Cowan, M.M. 1999. Plant products as antimicrobial agents. Clin. Microbiol. Rev., vol.12, no.4, pp.564-582.

Cuéllar, A. and González Yaque, J. 2010. Obtención del glucósido flavonoidegossypitrina de los pétalos de flores de Talipariti elatum S.w y evaluación de su posibleefecto antioxidante. Revista Colombiana de Ciencia Animal, 2, 338-348.

Cuéllar, A. and González, J. 2001. Phytochemistry Analysis of the Different Parts of theFlowers of Hibiscus elatus Sw. Revista Cubana de Farmacia, 35, 68-70.

Cushnie, T.P.T., and Lamb, A.J. 2005. Antimicrobial activity of flavonoids. Int. J. Antimicrobial Agents, vol.26, no. 5, pp. 343-356.

Frantz François-Haugrin, Max Monan, Emmanuel Nossin, Juliette Smith-Ravin and OdileMarcelin. 2016. Antioxidant activity of an isomer of gossypitrin (gossypetin-3'-O-glucoside)isolated in the petals of Talipariti elatum Sw., and determination of total phenolic content othe total flower. J. Pharmacognosy and Phytochem., 5(5): 200-208.

García-Alonso, J., Ros, G., Vidal-Guevara, L., Periago, J. 2006. Acute intake of phenolicric juice improves antioxidant status in healthy subjects. Nutr. Res., 26: 330-339.

Mahadevan, N., Shivali and Pradeep Kamboj. 2009. Hibiscus sabdariffa L.-An overview. Natural Product Radiance, 
Vol. 8(1), 2009, pp. 77-83.

Marjorie, C. 1999. Plant products as antimicrobial agents. Clin. Microbiol. Rev., 12:564-582. PMID: 10515903

Márquez, I., Cuéllar, A., Martínez, J., Alemán, A., Lora, J. and Castro, H. 1999. Estudiofitoquímico de la especie Hibiscus elatus S.w. Revista Cubana de Farmacia, 33, 127-131.

Mishra, A., Kumar, S., and Pandey, A.K. 2013. Scientific validation of the medicinal efficacyof Tinospora cordifolia. The Scientific World J., vol.2013, Article ID 292934.

Mishra, A., Kumar, S., Bhargava, A., Sharma, B., and Pandey, A.K. 2011. Studies on in vitroantioxidant and antistaphylococcal activities of some important medicinal plants. Cellular and Mol. Biol., vol.57, no.1, pp.16-25.

Mishra, A., Sharma, A.K., Kumar, S., Saxena, A.K., and Pandey, A.K. 2013. Bauhinia variegataleaf extracts exhibit considerable antibacterial, antioxidant and anticancer activities. BioMed. Res. Int., vol.2013, Article ID 915436, 10 pages.

Mishra, A.K., Mishra, A., Kehri, H.K., Sharma, B., and Pandey, A.K. 2009. Inhibitory activity ofIndian spice plant Cinnamomum zeylanicum extracts against Alternaria solani and Curvularialunata, the pathogenic dematiaceous moulds. Annals of Clin. Microbiol. Antimicrobials, vol.8, article 9.

Moerman, D.E. 1996. An analysis of the food plants and drug plants of native North America. J. Ethnopharmacol., vol. 52, no. 1, pp. 1-22.
Mori, A., Nishino, C., Enoki, N., and Tawata, S. 1987. Antibacterial activity and mode ofaction of plant flavonoids against Proteus vulgaris and Staphylococcus aureus. Phytochem., vol.26, no. 8, pp. 2231-2234.

Mounnissamy, V.M., Kavimaini, S., Gunasegaran, R. 2002. Antibacterial activity ofgossypetin isolated from Hibiscus sabdariffa. Antiseptic 99(3):81-82.

Nakahara, K., Kawabata, S., Ono, H. et al. 1993. Inhibitory effect of oolong tea polyphenolson glucosyltransferases of mutans streptococci. Appl. Environ. Microbiol., vol.59, no. 4, pp. 968-973.

Ohemeng, K.A., Schwender, C.F., Fu, K.P., and Barrett, J.F. 1993. DNA gyrase inhibitoryand antibacterial activity of some flavones(1). Bioorganic and Med. Chem. Lett., vol.3, no. 2, pp. 225230.Database.

Pandey, A.K., Mishra, A.K., Mishra, A., Kumar, S., and Chandra, A. 2010. Therapeutic potentialof $C$. zeylanicum extracts: an antifungal and antioxidant perspective. Int. J. Biol. Med. Res., vol.1, pp.228-233.

Rogger, Y.S., John, L.I., Mark, L.W. 1990. General Microbiology. 5th ed. Macmillan education Ltd London. pp. 626-642.

Yaque, J.G., Cuéllar, A., Gaysinski, M., Monan, M., Nossin, E. and FrançoisHaugrin, F. 2016. New Reported Flavonol Characterized by NMR from the Petals of Talipariti elatumS.w. in Cuba. American J. Plant Sci., 7, 15641569.http://dx.doi.org/10.4236/ajps.201 6.711148

\section{How to cite this article:}

José González, Armando Cuéllar, Loïk Sylvius, Frédéric Verdeau, Juliette Smith-Ravin and Odile Marcelin. 2016. Antibacterial and Antifungal Activities of Gossypitrin from Talipariti elatum Sw. (Fryxell). Int.J.Curr.Microbiol.App.Sci. 5(11): 860-866.

doi: http://dx.doi.org/10.20546/ijcmas.2016.511.098 